\title{
A Comparative Analysis Between The Balanced Scorecard And The French Tableau de Bord
}

\author{
Mohsen Souissi, Fayetteville State University
}

\begin{abstract}
Concern over the development of new performance measurement systems that that are in line of a complex business environment has increased. Problems with relying solely on financial measures have proven counterproductive. Recently, interest over non-financial measures has dramatically increased. Non-financial measures, however, are not problem-free. The issues are to translate improvements in these non-financial indicators into improvement in the bottom line. To overcome these problems, Kaplan and Norton have developed a new system called the Balanced Scorecard (BSC). Some French scholars argue that the BSC is a mere reproduction of the French Tableau de Bord (TDB) developed in the 1950s by French engineers. This paper seeks to draw a comparison between the BSC and The TDB.
\end{abstract}

\section{INTRODUCTION}

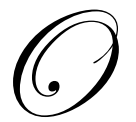

rganizations nowadays are increasingly unsatisfied with their performance measurement systems. They are concerned about the limitations of the financial measures they have been traditionally using to keep track of their performance. The shortcomings of the financially based measures sparked a considerable debate among both academicians as well as practitioners. A survey of this literature will be presented in the following section.

In order to address the limitation of a system that overemphasizes financial figures, Kaplan and Norton created a tool they call the BSC which measures the company's performance across four perspectives: financial, customer, internal business, and learning and growth perspectives. Kaplan and Norton claim that the measures along the four perspectives are derived from the organization's strategy and tied together through a cause-and-effect relationships. Some French scholars are not very enthusiastic about the originality of the idea underlying the BSC and argue that it is, to a great extent, similar to the TDB measurement system devised by French engineers at the turn of the $20^{\text {th }}$ century (Mevellec, 1993). This paper will be divided in two sections. Section 1 will survey the literature and section 2 will draw a comparison between the two systems while highlighting the social context within which each tool evolved.

\section{BACKGROUND AND LITERATURE REVIEW}

The design of an effective measurement systems have proven very challenging, particularly in light of the dramatic change of the business and manufacturing environments we have witnessed during the last three decades or so. Traditional, financially based performance measures were, at best, unable to cope with the requirements of the new environment (Shank \& Govindarajan, 1993). Kaplan \& Johnson (1987) argue that these financial measures are 'too late and too aggregate to be of use to managers'. They further argue that these financial measures were misleading by distracting managers away from real problems.

Non-financial measures such as customer satisfaction, quality of products, delivery time, low inventory, flexibility etc., are forward looking measures that can help managers take corrective actions on time. Johnson (1990) 
went further to suggest that customer satisfaction is the key to organizational success. However, while the non financial measures are at least of equal importance to financial measures, they are not problem free (Shank \& Govindarajan , 1993). The problem is how to translate improvements along non-financial indicators into improvements in the bottom line. Lebas (1994) notes that understanding the link between financial information and non-financial information and integrate them into an information system is a major challenge facing accountants. That link became less and less evident especially when some of the winners of quality awards failed to perform well in the market place.

To address the shortcoming of relying solely on a set of indicators at the expense of others, Kaplan and Norton (1992) devised a new framework to integrate financial and non-financial measures. The new framework called the balanced scorecard (BSC) attempts to link a comprehensive measurement system (e.g., a mixture of financial and non financial measures) to the organization's strategy. Some French scholars argue that idea of the BSC is not new and it represents a mere reproduction of the TDB developed and used by French engineers towards the 1930s.

The following section will attempt to shed light on the two systems and draw a comparison between the BSC and the TDB.

\section{COMPARISON BETWEEN THE BSC AND THE TDB}

This section will highlight the major differences between the BSC and the TDB.

\section{STRATEGIC EMPHASIS VERSUS OPERATIONAL EFFECTIVENESS}

It is interesting to note that at its inception the BSC was designed as a comprehensive measurement system that attempts to address the shortcomings of the heavily market-oriented financial indicators. Later on, Kaplan and Norton (2004) claim that the balanced scorecard has evolved into a strategic tool that aims to tie the strategic goals into a set of carefully designed measures. The measures ensure that the organization is on track towards achieving its strategic objectives. Kaplan and Norton (1996) state that the BSC is a bottom up approach whose successful implementation depends largely on top management involvement and commitment. They note that the " the scorecard starts with senior executive management team working together to translate its business unit's strategy into specific strategic objectives" (Kaplan and Norton, 1996, p.10). They also argue the BSC measures should be cascaded down to lower levels but they did not elaborate on how the synchronization between different levels of management is achieved. It is no surprise that this synchronization represents a tough challenge facing organizations implementing the BSC.

On the other hand, the TDB does not explicitly mention the link between the devised measures and the strategy (Epstein and Manzoni, 1997). It is important to note that French organizations operated in a rather stable environment heavily regulated by the government and thus did not need extensive information about the competition to run their operations. In that respect, the TDB metrics were internally oriented. Managers-engineers tend to place a heavier emphasis on tangible, short-term operational issues. Engineers were more occupied with daily operations and less with strategic issues.

\section{FINANCIAL PEOPLE VERSUS ENGINEERS}

The BSC and the TDB stem from two different perspectives. According to Bourguignon et al (2004), these two tools "bear the marks of their original social context" (p-3).

The latter is the product of a domination of financial people and the strong role they generally play within US organizations. Since they are rewarded on the basis of financial figures, understandably these financial people ultimate concern is to improve the bottom line and send good signals to Wall Street. The BSC is created within the framework of a market-oriented approach. It is no surprise that the financial success is the ultimate perspective that springs off the other three perspectives. In that respect, Kaplan (2006) notes that the BSC "is also grounded in the 
financial economist's shareholder value maximization principle..." p.133. It is puzzling that though the BSC articulates around four perspectives, financial people are hardly rewarded on other the basis than bottom line.

The former, however, reflects the power of engineers. The French engineers were not heavily constrained by market demands, as is the case in the US. They were not therefore under the pressure to focus significantly on the bottom line. They were more process oriented than profit oriented. In contrast, the TDB is more of a productionoriented approach since all the measures are designed to keep track of the production process with an emphasis on yield, productivity rates, and efficiency of operations. Financial indicators while important are not as much emphasized as in the BSC.

The difference in focus could be partly attributed to that fact that, towards late $19^{\text {th }}$ and early $20^{\text {th }}$ centuries, French engineers steered organizations that were shielded by government regulations and protection. According to Lebas (1994), the state played a major role in the economy and state mandated prices were still in use until 1975.

It is also important to note that the collection of information required for the TDB is in line with a bottomup approach. That is the information is generated from the shop floor and made available for engineers at the top level to manage the production process and more importantly take decisions. As such, in France, management is not a function in its own, divorced from production

\section{CONCLUSION}

Though they are both grounded in the same philosophy emphasizing the marriage between financial measures and non-financial measures, the BSC and the French TDB differs in many aspects. While the BSC emphasizes the link between the devised financial and non-financial measures with the strategic orientations of the organization, the TDB is more of an operational tool that aims to manage and control the production process. In addition, as a bottom up approach, the BSC reflects the power of financial people within American organizations, thus emphasizing the bottom line. In contrast, the TDB is a tool designed by engineers to steer their companies and emphasizes physical measures such as productivity, yields. Financial indicators in the TDB while important are not as much emphasized as in the BSC.

\section{AUTHOR INFORMATION}

Dr. Mohsen Souissi is Assistant Professor of Accounting at Fayetteville State University. He holds a Ph.D. in Accounting. He is a Certified Management Accountant (CMA). He teaches principles of accounting, cost accounting, and management accounting. He has a number of publications in various academic journals such as The International Journal of Management, the Journal of Corporate Accounting and Finance, the Journal of Business and Global Economic Review. His research interests include Activity-Based Costing, Target Costing, Corporate Governance, the Balanced Scorecard. Based on his scholarly contributions in academia, Dr. Souissi has been nominated and listed in Marquis Who's Who Amongst America's Teachers.

\section{REFERENCES}

1. Bourguignon, A., Malleret.V. and Norreklit.H (2004). Balanced scorecard versus French tableau de bord: The ideological perspective, Management Accounting Research, Vol.15, no.2, pp.107-134.

2. Epstein, M.J. and J. Manzoni (1997). The balanced scorecard and the tableau de bord: Translating strategy into action, Management Accounting, Aug, pp. 28-36.

3. Johnson, H.T and Kaplan, R.S (1987). Relevance lost: The rise and fall of management accounting. Boston, MA: Harvard Business School Press.

4. Johnson, H.T.(1992). Relevance regained: From top-down control to bottom-up empowerment, New York: The Free Press.

5. Kaplan, R.S. (2006). The competitive advantage of management accounting, Journal of Management Accounting Research, Vol.18, pp.127-135. 
6. Kaplan, R.S. and D.P. Norton (1996). The balanced scorecard: translating strategy into actions. Boston, MA: Harvard Business School Press.

7. Kaplan, R.S. and D.P. Norton (2004). Strategy maps: converting intangible assets into tangible outcomes. Boston, MA: Harvard Business School Press.

8. Lebas, M. (1994), Management accounting in France: Overview of past and current practice, European Accounting Review, Vol.3, No.3, pp.471-487

9. Mevellec, P. (1993). Plaidoyer pour une vision Francaise de la methode ABC, Revue Francaise de la Comptabilite, December, pp.36-44.

10. Shank, J.K. and Gonindarajan, V. (1993), Strategic cost managemnt: the new tool for competitive advantage, New York: Free Press.

NOTES 